\title{
Pengembangan Instrumen Penilaian Keterampilan Berpikir Kritis Pembelajaran IPA Kelas 4 SD
}

\author{
Alycia Novena Nugroho ${ }^{1 *}$, Gamaliel Septian Airlan² iD \\ ${ }^{123}$ Program Studi Pendidikan Guru Sekolah Dasar, Universitas Kristen Satya Wacana, Salatiga, Indonesia \\ *Corresponding author:292016038@student.uksw.edu
}

\section{Abstrak}

Masalah yang dihadapi tentang proses penilaian di seolah dimana guru cenderung memberikan soal dengan tingkatan kognitif rendah dan jawaban singkat, sehingga kurang diperhatikannya keterampilan berpikir kritis siswa. Penelitian ini bertujuan untuk mendeskripsikan kelayakan instrumen penilaian keterampilan berpikir kritis pembelajaran IPA kelas 4 SD. Jenis penelitian yang digunakan pada penelitian ini adalah desain penelitian dan pengembangan (Research and Development). Subjek penelitian ini adalah Intrument penilain keterampilan berpikir Kritis. Hasil analisis pada 15 butir soal uraian validitas menurut review para ahli diperoleh hasil yang baik. Berdasarkan hasil validasi dari pakar materi dinyatakan valid dan kelayakan mencapai angka 77\%. Hasil validasi pakar instrumen dinyatakan valid dan kelayakan mencapai angka 70,5\%. Sedangkan hasil validasi pakar bahasa mencapai angka 75,5\%. Instrumen peniliaian yang telah dikembangkan dalam penelitian ini dinyatakan valid dan dapat digunakan sebagai penilaian keterampilan berpikir kritis IPA untuk siswa kelas 4 SD.

Keywords: Instrumen Penilaian, Keterampilan Berpikir Kritis, Sains

\section{Abstract}

The problems faced with the assessment process are where teachers tend to give questions with low cognitive levels and short answers, resulting in a lack of attention to students' critical thinking skills. This study aims to describe the feasibility of critical thinking skills assessment instruments in grade 4 elementary school science. The type of research used in this research is research and development design. The subject of this study was the Iintrument of Critical thinking skills assessment. The results of the analysis on 15 points about the description of validity according to the review of experts obtained good results. Based on validation results from material experts declared valid and feasibility reached the figure of $77 \%$. The validation result of the instrument expert is declared valid and the feasibility reaches $70.5 \%$. While the validation results of language experts reached the figure of $75.5 \%$. The research instruments developed in this study are declared valid and can be used as an assessment of science critical thinking skills for grade 4 elementary school students.

Keywords: Assessment Instruments, Critical Thinking Skills, Science

\section{Introduction}

Penilaian tidak bisa terlepas dari proses pembelajaran, karena dengan adanya penilain pendidik akan tahu bagaimana capain pembelajaran. Penilaian hasil belajar oleh satuan pendi- dikan dilakukan untuk menilai pencapaian kompetensi siswa pada semua mata pelajaran.(Amalia \& Susilaningsih, 2014; Putri et al., 2019; Sukmawa et al., 2019). Penilaian menjadi tugas dan tanggung jawab dari pendidik dalam pembelajaran yang berfungsi untuk menilai sejauh mana siswa dapat mencapai tujuan dari pembelajaran. Proses penilaian harus melewati tahapan pengumpulan informasi yang bertujuan untuk mengambil keputusankeputusan tentang kebijakan pendidikan, mutu program pendidikan, mutu kurikulum, mutu pengajaran dan sejauh mana pengetahuan yang didapatkan oleh siswa. Kegiatan penilaian yang dilakukan oleh guru dapat dimaknai sebagai bagian dari sistem pembelajaran yang direncanakan dan dilaksanakan di kelas. Proses penilaian tidak bisa terlepas dari Intrument

$\begin{array}{ll}\text { History: } & \\ \text { Received } & : 24 \text { August } 2020 \\ \text { Revised } & : 1 \text { September } 2020 \\ \text { Accepted } & : 26 \text { September } 2020 \\ \text { Published } & : 1 \text { Desember } 2020\end{array}$

Publisher: Undiksha Press

Licensed: This work is licensed under

a Creative Commons Attribution 3.0 License

Published : 1 Desember 2020 
karena instrument penelian yang baik akan menggambarkan bagaimana keberhasian dari proses pembelajaran. Instrumen penilaian merupakan bagian integral dari suatu proses penilaian dalam pembelajaran, apa yang hendak diukur terkait dengan ketersediaan alat ukur yang dikembangkan, apa yang diukur dalam pembelajaran juga menentukan kualitas pembelajaran (Khaerunnisa \& Pamungkas, 2018). Penilaian ranah kognitif dapat dilakukan dengan beberapa teknik antara lain tes tertulis, tes lisan dan penugasan. Tes tertulis merupakan salah satu jenis instrumen yang dapat digunakan oleh guru untuk mengukur kemampuan kognitif siswa dalam memahami materi pelajaran yang diberikan. Dapat dikatakan bahwa dengan adanya instrument yang baik dan proses penilaian yang baik pendidik akan tahu bagaiaman kualitas adari pembelajaran.

Namun pada kenyataanya, belum semua guru menerapkan asesmen secara menyeluruh. Guru masih menggunakan asesmen secara tertulis untuk menilai hasil belajar siswa. Padahal asesmen secara tertulis hanya mencakup aspek kognitif saja, belum mencakup aspek afektif dan psikomotor (Sukmawa et al., 2019). Kenyataannya kemampuan guru dalam membuat instrumen penilaian belum memenuhi kriteria penilaian tes yang baik (Juniarta \& Winarno, 2016) masalah lainnya adalah instrument yang dibuat tidak dapat menilai aspek2 yang harusnya dinilai (Saputri et al., 2018). Hal ini sedana dengan hasil observai yang dilakukan di SD Kristen Widya Wacana telah ditemukan permasalahan sebagai diantaranya kurang diperhatikannya keterampilan berpikir kritis dalam mendesain instrumen pembelajaran yang akan digunakan, sehingga tidak terungkap keterampilan berpikir kritis yang dimiliki siswa. Jenis tes yang digunakan oleh guru cenderung memberikan jawaban singkat dan tidak memancing siswa dalam memberikan jawaban yang mengasah keterampilan berpikir kritis siswa. Butir soal yang digunakan dalam tes tidak pernah di uji tingkat validitas jadi butir soal layak atau tidak layak belum diketahui. Jika hal ini terus dilakukan ini akan sangat berdanpak terhadap kemampuan berpikir kritis siswa dimana berpikir kritis adalah salah satu penentu dari keberhasilan siswa dalam proses pembelajaran.

Berpikir kritis merupakan komponen penting yang harus dimiliki oleh setiap siswa, karena seiring dengan perkembangan teknologi dan ekonomi yang begitu pesat, setiap waktu seseorang dituntut untuk berpikir kritis, tidak hanya menerima sesuatu informasi begitu saja, namun harus bisa memilah-milih informasi yang diterimanya serta mencari sebab akibat dan buktinya secara logis dan rasional (Firdaus et al., 2019; Ikhsan et al., 2017; Marfilinda et al., 2019). Untuk mengembangkan kemampuan berpikir kritis siswa, bukan hanya dengan mengunkan model pembelajarn saja atau sekedar media pembelajaran tetapi instrument penilaian yang dibuatpun harus merangsang siswa berpikir kritis. Kemampuan berpikir siswa dapat dikem bangkan melalui program pembelajaran terutama yang berhubungan dengan proses kognitif penalaran melalui proses latihan menjawab soal yang berorientasi pada kemampuan berpikir tingkat tinggi (Mustikasari et al., 2018). Hal ini sesaui dengan penelitian yang dilakukan sebelumnya.

Penelitian yang dilakukan oleh Hasan et al., (2020) menunjukan bahwa Hasil analisis validitas butir soal menunjukkan bahwa butir-butir soal mendukung validitas tes sehingga dikatakan layak atau valid, sedangkan reliabilitas butir soal dinyatakan reliabel dengan nilai reliabilitas 0,897 dengan interpretasi tinggi. Analisis tingkat kesukaran instrumen diperoleh rata-rata skor sebesar 0,64 dengan kategori sedang. Daya pembeda instrumen menunjukkan kategori baik dengan nilai rata-rata sebesar 0,49. Kepraktisan instrumen yang dinilai oleh guru diperoleh persentase sebesar 92,5\% dengan kategori sangat praktis. Hasil analisis kemampuan berpikir kritis peserta didik diperoleh bahwa rata-rata kemampuan berpikir kritis peserta didik berada pada kategori sedang. Penelitian Fazriani et al.,( 2019) menunjukkan Terdapat perbedaan yang signifikan terhadap hasil belajar siswa, dibuktikan dalam Uji-t diperoleh thitung > ttabel $(13.69>2.042)$ dan uji Wilcoxon Sign rank yang menghasilkan nilai (asym.sig. (2- tailed)) adalah $0.000<0.05$ maka hasil hipotesis H0 ditolak dan H1 
diterima. Hal ini dapat disimpulkan bahwa terdapat pengaruh hasil belajar pada kemampuan berpikir siswa pada saat pembelajaran dengan menggunakan pendekatan Higher Order Thinking Skill (HOTS) terhadap keterampilan membaca siswa. penelitian Wijaya et al., (2017) menunjukkan bahwa Penelitian berupa uji validitas butir soal memenuhi kriteria valid sebanyak 17 soal dan memiliki kriteria valid berdasarkan empat pakar dengan reliabilitas instrumen penilaian memenuhi kriteria reliabel. Tingkat kesukaran soal memenuhi kriteria sedang dan sukar dengan daya beda soal yaitu baik. Siswa yang memiliki kemampuan berpikir kritis adalah $11 \%$. Keefektifan instrumen diperoleh dari nilai post?test siswa, menunjukan bahwa instrumen efektif menggukur kemampuan berpikir kritis secara objektif dan dapat membedakan kemampuan berpikir kritis siswa. Simpulan dari penelitian ini adalah instrumen penilaian berpikir kritis dengan pendekatan SETS efektif mengukur kemampuan berpikir kritis siswa.

Tujuan penelitian ini adalah untuk mendeskripsikan kelayakan instrumen penilaian keterampilan berpikir kritis pembelajaran IPA kelas 4 SD. Dengan instrument yang layak diharapakn kemapuan siswa dalam memecahkan masalah dan mampu mengebangakan keterampilan berpikir kritis. Sehingga proses pembelajaran lebih bermakna dan secara langsung berdanpak terhadap kualitas Pendidikan yang dihasilkan.

\section{Materials and Methods}

Jenis penelitian yang digunakan pada penelitian ini adalah desain penelitian dan pengembangan (Research and Development). (Rodiawati \& Komarudin, 2018)Research and Development (R\&D) merupakan metode penelitian yang digunakan untuk mengembangkan atau memvalidasi produk-produk yang digunakan dalam pendidikan dan pembelajaran. Pengumpulan data dilakukan dengan metode wawancara dan observasi. Selanjutnya melakukan pengembangan desain produk. Kemudian produk pengembangan instrumen keterampilan berpikir kritis pembelajaran IPA dan perubahannya dilakukan penyempurnaan secara bertahap melalui penilaian atau validasi dari berbagai ahli instrumen. Penelitian pengembangan (Research and Development) yang didefinisikan diatas dapat disimpulkan R\&D sebagai penelitian yang dilakukan dalam rangka pengembangan suatu produk. Produk yang dikembangkan dalam penelitian ini adalah instrumen penilaian keterampilan kemampuan berpikir kritis siswa. Pada penelitian pengembangan dikembangkan produk penilaian, yaitu penilaian keterampilan berpikir kritis. Penilaian yang dikembangkan pada penelitian ini, yaitu instrument penilaian keterampilan berpikir kritis pada pembelajaran IPA Kelas IV tema 2 Subtema 2, produk pengembangan yang akan dihasilkan berupa instrument penilaian keterampilan berpikir kritis dalam bentuk hardcopy.

\section{Results and Discussion}

Pengembangan instrumen penilaian keterampilan berpikir kritis dimulai dengan melakukan studi pendahuluan terdiri dari survei lapangan dan studi kepustakaan. Survei lapangan dilakukan observasi dan wawancara ke sekolah untuk menganalisis kebutuhan guru. Sedangkan dalam studi kepustakaan mengumpulkan informasi yang berkaitan dengan pengembangan instrumen penilaian, tujuan pendidikan nasional, teori tentang berpikir kritis, serta penelitian terdahulu yang terkait. Tahap observasi dilakukan agar mengetahui potensi keterampilan berpikir kritis pembelajaran IPA. Desain produk diawali dengan memilih kelas yang dijadikan subjek penelitian. Setelah itu menentukan KI dan KD pada mata pelajaran IPA kelas IV. Instrumen disini digunakan untuk mengukur aspek penilaian kognitif. Aspek kognitif menunjukkan tingkatan pengetahuan yang meliputi ingatan atau hafalan, pemahaman, penerapan atau aplikasi, analisis, evaluasi dan membuat. 
Pengembangan instrumen penilaian kognitif menghasilkan produk instrumen penilaian kognitif berupa butir soal. Setelah itu peneliti menyusun kisi-kisi soal pengembangan keterampilan berpikir kritis. Kisi-kisi soal memuat indikator keterampilan berpikir kritis dan indikator kurikulum 2013. Peneliti menyusun soal untuk mengembangkan instrumen penialaian yang mengacu pada keterampilan berpikir kritis menurut Ennis (1985). Robert Ennis menggolongkan keterampilan berpikir kritis pada lima aspek, dua belas indikator dan beberapa sub indikator. Model soal yaitu soal uraian yang terdapat 15 soal. Menyusun kunci jawaban disertai penyekoran tiap nomor. Kunci jawaban dan penskoran disesuaikan dengan tiap nomor soalnya. Lembar soal siswa setiap aspek memiliki skor tertinggi sama dengan 4. Desain produk yang sudah dirancang oleh peneliti kemudian dilakukan validasi kepada ahli instrumen, ahli materi IPA, dan ahli bahasa. Instrumen penilaian yang telah divalidasi oleh pakar dan dinyatakan valid, maka instrumen penilaian dapat diujicobakan. Tetapi karena adanya pandemi Covid-19 maka penelitian berhenti sampai uji validasi dari ahli pakar.

Produk pengembangan instrumen keterampilan berpikir kritis pembelajaran IPA dan perubahannya telah dilakukan penyempurnaan secara bertahap melalui penilaian atau validasi dari berbagai ahli instrumen. Adapun validasi dilakukan oleh ahli materi IPA, ahli instrumen, dan ahli bahasa. Validasi ini dilakukan untuk menilai produk yang telah dikembangkan, maka selanjutnya dilakukan penyempurnaan melalui revisi sesuai kritik dan saran dari ahli pengembang instrumen penilaian. setelah hasil penilaian validasi dilakukan selanjutnya adalah menganalisis data kuantitatif berupa skor penilaian dari instrumen validasi berupa angket.

\section{Hasil Validasi Pakar Materi}

Validasi pakar materi dilakukan oleh dua validator. Penilaian yang diberikan oleh masing-masing validator mendapatkan hasil yang berbeda-beda begitu juga dengan saran perbaikannya. Setelah melakukan analisis terhadap validasi oleh dosen ahli materi diketahui bahwa kelayakan mencapai angka 77\%. Hasil menunjukan bahwa produk layak digunakan, akan tetapi masih perlu diperbaiki sesuai kritik dan saran dari setiap validator. Validasi pakar materi juga menghasilkan data yang bersifat kualitatif yang berupa kritik dan saran dari validator. Beberapa catatan dan saran perbaikan terhadap instrumen yang dikembangkan adalah sebagai berikut: Kompetensi Inti belum dicantumkan pada instrument, Kisi-kisi soal nomor 3 dan 4 tidak sesuai dengan soal, Jawaban No. 11 perlu diperbaiki, Ada beberapa soal masih dijenjang C2. Maka solusi ditambahkan cerita sebagai tambahan pengetahuan sehingga siswa mampu melakukan metakognisi dari cerita sebelumnya dan Soal nomor 7 ditambahkan gambar agar dapat menunjukan bagian mana yang disentuh pada radio tersebut. Tahap selanjutnya adalah melakukan perbaikan sesuai kritik dan saran. Saran yang didapatkan pada instrumen angket digunakan untuk bahan pertimbangan perbaikan instrumen keterampilan berpikir kritis. Validasi pada ahli materi memerlukan 1 kali revisi dan dinyatakan valid.

\section{Hasil Validasi Pakar Instrumen}

Validasi pakar instrumen dilakukan oleh dua validator. Penilaian yang diberikan oleh masing-masing validator mendapatkan hasil yang berbeda-beda. Setelah melakukan analisis terhadap validasi oleh dosen ahli instrumen diketahui bahwa kelayakan mencapai angka $70,5 \%$. Hasil menunjukan bahwa produk layak digunakan, akan tetapi masih perlu diperbaiki sesuai kritik dan saran dari setiap validator. Validasi pakar materi juga menghasilkan data yang bersifat kualitatif yang berupa kritik dan saran dari validator. Hasil revisi produk berasal dari komentar dan saran dari para Ahli instrumen. Beberapa catatan dan saran perbaikan terhadap instrumen yang dikembangkan adalah sebagai berikut: Kriteria jawaban harus dirinci dengan jelas. Dan Beberapa jawaban tidak menjawab pertanyaan (nomor 5 dan 10) 
Tahap selanjutnya adalah melakukan perbaikan sesuai kritik dan saran. Kritik dan saran dari ahli instrumen pembelajaran IPA dalam pertanyaan terbuka dan didapatkan pada instrumen anget dijadikan sebagai bahan pertimbangan untuk melengkapi dan memperbaiki instrumen keterampilan berpikir kritis yang dikembangkan sehingga menjadi lebih berkualitas. Produk instrumen keterampilan berpikir kritis pembelajaran IPA memerlukan 1 kali revisi dan dinyatakan valid oleh ahli instrumen.

\section{Hasil Validasi Pakar Bahasa}

Validasi pakar instrumen dilakukan oleh dua validator. Presentase hasil validasi oleh 2 dosen ahli bahasa pada 11 komponen penilaian terhadap instrumen keterampilan berpikir kritis pembelajaran IPA. Penilaian yang diberikan oleh masing-masing validator mendapatkan hasil yang berbeda-beda begitu juga dengan saran perbaikannya. Setelah melakukan analisis terhadap validasi oleh dosen ahli bahasa diketahui bahwa kelayakan mencapai angka 75,5\%. Hasil menunjukan bahwa produk layak digunakan, akan tetapi masih perlu diperbaiki sesuai kritik dan saran dari setiap validator. Hasil revisi produk berasal dari komentar dan saran dari para Ahli bahasa. Adapun komentar tersebut adalah Bahasa yang belum baku sehingga ada beberapa kata dan kalimat masih harus diperbaiki agar menjadi kalimat efektif, dan mudah dipahami oleh siswa. Saran yang didapatkan pada instrumen angket digunakan untuk bahan pertimbangan perbaikan instrumen keterampilan berpikir kritis. Validasi pada ahli bahasa memerlukan 1 kali revisi dan dinyatakan valid.

\section{Revisi Produk}

Hasil menunjukan bahwa produk layak digunakan, akan tetapi masih perlu diperbaiki sesuai kritik dan saran dari setiap validator. Hasil revisi produk berasal dari komentar dan saran dari para Ahli. Adapun hasil revisi tersebut akan dipaparkan dalam tabel 1 berikut:

Tabel 1. Hasil Revisi

\begin{tabular}{|c|c|c|c|}
\hline No. & Komponen & Sebelum Revisi & Sesudah Revisi \\
\hline 1 & Kompetensi Inti & $\begin{array}{l}\text { Kompetensi Inti belum dicantumkan } \\
\text { sebelum kisi-kisi soal. }\end{array}$ & $\begin{array}{lr}\text { Kompetensi } & \text { Inti } \\
\text { dicantumkan } & \text { sebelum } \\
\text { kisi-kisi soal. } & \end{array}$ \\
\hline 2 & Kisi-kisi & $\begin{array}{l}\text { Kisi-kisi soal nomor } 3 \text { dan nomor } 4 \\
\text { terbalik sehingga tidak sesuai antara } \\
\text { kisi-kisi, soal, dengan jawaban }\end{array}$ & $\begin{array}{lr}\text { Penulis } & \text { melakukan } \\
\text { perbaikan dengan } \\
\text { membalikkan soal }\end{array}$ \\
\hline 3 & Soal & $\begin{array}{l}\text { Beberapa soal perlu adanya } \\
\text { tambahan cerita dan penambahan } \\
\text { gambar pada soal }\end{array}$ & $\begin{array}{l}\text { Soal sudah ditambahkan } \\
\text { soal cerita dan sudah } \\
\text { ditambahkan gambar } \\
\text { pada soal }\end{array}$ \\
\hline 4 & Jawaban Soal & $\begin{array}{l}\text { Beberapa jawaban tidak menjawab } \\
\text { pertanyaan }\end{array}$ & $\begin{array}{l}\text { Jawaban sudah } \\
\text { disesuaikan dengan soal }\end{array}$ \\
\hline 5 & Rubrik penilaian & $\begin{array}{l}\text { Kriteria jawaban belum dirinci } \\
\text { dengan jelas }\end{array}$ & $\begin{array}{l}\text { Kriteria jawaban sudah } \\
\text { dirinci dengan jelas }\end{array}$ \\
\hline 6 & Bahasa & $\begin{array}{l}\text { Bahasa yang belum baku sehingga } \\
\text { ada beberapa kata dan kalimat masih } \\
\text { harus diperbaiki agar menjadi } \\
\text { kalimat efektif, dan mudah dipahami } \\
\text { oleh siswa. }\end{array}$ & $\begin{array}{l}\text { Bahasa sudah } \\
\text { disesuaikan dengan kata } \\
\text { dan kalimat yang baku } \\
\text { sehingga soal sudah } \\
\text { menjadi kalimat efektif, } \\
\text { dan mudah dipahami } \\
\text { oleh siswa. }\end{array}$ \\
\hline
\end{tabular}


Hasil penelitian menunjukkan bahwa cara mengembangkan instrumen penilaian kognitif dimulai dengan melakukan studi pendahuluan terdiri dari survei lapangan dan studi kepustakaan. Kemudian peneliti menentukan KI dan KD pada mata pelajaran IPA kelas IV. Instrumen penilaian berpikir kritis yang dikembangkan telah memenuhi kriteria kaidah penulisan soal. Kevalidan instrumen dibuktikan dengan hasil penilaian ahli pakar yang menunjukkan bahwa instrumen layak digunakan berdasarkan telaah aspek materi, instrumen, dan bahasa.

Pembelajaran yang menekankan perilaku berpikir kritis dapat dilihat saat berlangsungnya proses pembelajaran, diskusi, presentasi, dan penyelesaian tugas siswa. Berpikir kritis merupakan komponen penting yang harus dimiliki oleh setiap siswa, karena seiring dengan perkembangan teknologi dan ekonomi yang begitu pesat, setiap waktu seseorang dituntut untuk berpikir kritis, tidak hanya menerima sesuatu informasi begitu saja, namun harus bisa memilah-milih informasi yang diterimanya serta mencari sebab akibat dan buktinya secara logis dan rasional (Firdaus et al., 2019; Ikhsan et al., 2017; Marfilinda et al., 2019). Untuk mengembangkan kemampuan berpikir kritis siswa, bukan hanya dengan mengunkan model pembelajarn saja atau sekedar media pembelajaran tetapi instrument penilaian yang dibuatpun harus merangsang siswa berpikir kritis. Kemampuan berpikir siswa dapat dikem bangkan melalui program pembelajaran terutama yang berhubungan dengan proses kognitif penalaran melalui proses latihan menjawab soal yang berorientasi pada kemampuan berpikir tingkat tinggi (Mustikasari et al., 2018). Hal ini sesaui dengan penelitian yang dilakukan sebelumnya.

Penelitian yang dilakukan oleh Hasan et al., (2020) menunjukan bahwa Hasil analisis validitas butir soal menunjukkan bahwa butir-butir soal mendukung validitas tes sehingga dikatakan layak atau valid, sedangkan reliabilitas butir soal dinyatakan reliabel dengan nilai reliabilitas 0,897 dengan interpretasi tinggi. Analisis tingkat kesukaran instrumen diperoleh rata-rata skor sebesar 0,64 dengan kategori sedang. Daya pembeda instrumen menunjukkan kategori baik dengan nilai rata-rata sebesar 0,49. Kepraktisan instrumen yang dinilai oleh guru diperoleh persentase sebesar 92,5\% dengan kategori sangat praktis. Hasil analisis kemampuan berpikir kritis peserta didik diperoleh bahwa rata-rata kemampuan berpikir kritis peserta didik berada pada kategori sedang. Penelitian Fazriani et al.,( 2019) menunjukkan Terdapat perbedaan yang signifikan terhadap hasil belajar siswa, dibuktikan dalam Uji-t diperoleh thitung > tabel $(13.69>2.042)$ dan uji Wilcoxon Sign rank yang menghasilkan nilai (asym.sig. (2- tailed)) adalah $0.000<0.05$ maka hasil hipotesis H0 ditolak dan H1 diterima. Hal ini dapat disimpulkan bahwa terdapat pengaruh hasil belajar pada kemampuan berpikir siswa pada saat pembelajaran dengan menggunakan pendekatan Higher Order Thinking Skill (HOTS) terhadap keterampilan membaca siswa. penelitian Wijaya et al., (2017) menunjukkan bahwa Penelitian berupa uji validitas butir soal memenuhi kriteria valid sebanyak 17 soal dan memiliki kriteria valid berdasarkan empat pakar dengan reliabilitas instrumen penilaian memenuhi kriteria reliabel. Tingkat kesukaran soal memenuhi kriteria sedang dan sukar dengan daya beda soal yaitu baik. Siswa yang memiliki kemampuan berpikir kritis adalah 11\%. Keefektifan instrumen diperoleh dari nilai post?test siswa, menunjukan bahwa instrumen efektif menggukur kemampuan berpikir kritis secara objektif dan dapat membedakan kemampuan berpikir kritis siswa. Simpulan dari penelitian ini adalah instrumen penilaian berpikir kritis dengan pendekatan SETS efektif mengukur kemampuan berpikir kritis siswa.

\section{Conclusion}

Hasil penelitian menunjukkan bahwa cara mengembangkan instrumen penilaian kognitif dimulai dengan melakukan studi pendahuluan terdiri dari survei lapangan dan studi kepustakaan. Kemudian peneliti menentukan KI dan KD pada mata pelajaran IPA kelas IV. 
Instrumen penilaian berpikir kritis yang dikembangkan telah memenuhi kriteria kaidah penulisan soal. Kevalidan instrumen dibuktikan dengan hasil penilaian ahli pakar yang menunjukkan bahwa instrumen layak digunakan berdasarkan telaah aspek materi, instrumen, dan bahasa. Berdasarkan hasil validasi dari pakar materi dinyatakan valid dan kelayakan mencapai angka 79,4\%. Hasil validasi pakar instrumen dinyatakan valid dan kelayakan mencapai angka 70,5\%. Sedangkan hasil validasi pakar bahasa mencapai angka 75,5\%. Jadi instrumen penilaian keterampilan berpikir kritis pembelajaran IPA kelas IV SD dinyatakan layak digunakan atau diujicobakan di lapangan dengan revisi sesuai saran.

\section{References}

Amalia, N. F., \& Susilaningsih, E. (2014). Pengembangan Instrumen Penilaian Keterampilan Berpikir Kritis Siswa Sma Pada Materi Asam Basa. Jurnal Inovasi Pendidikan Kimia, $8(2)$, 1380-1389. https://journal.unnes.ac.id/nju/index.php/JIPK/article/viewFile/4443/3807

Fazriani, N., Supendi, D. A., \& Humaira, H. W. (2019). Pengaruh Pendekatan Higher Order Thinking Skill (HOTS) Terhadap Keterampilan Membaca Siswa Kelas X SMK Negeri 3 Kota Sukabumi. Stilistika: Jurnal Pendidikan Bahasa Dan Sastra, 12(2), 124-138. https://doi.org/10.30651/st.v12i2.2802

Firdaus, A., Nisa, L. C., \& Nadhifah, N. (2019). Kemampuan Berpikir Kritis Siswa pada Materi Barisan dan Deret Berdasarkan Gaya Berpikir. Jurnal, 10(1), 68-77. https://doi.org/10.15294/kreano.v10i1.17822

Hasan, S. W., Auliah, A., \& Herawati, N. (2020). Pengembangan Instrumen Penilaian Kemampuan Berpikir Kritis Siswa SMA. Chemistry Education Review, 3(2), 1851939. https://doi.org/https://doi.org/10.26858/cer.v3i2.13769

Ikhsan, M., Munzir, S., \& Fitria, L. (2017). Kemampuan Berpikir Kritis dan Metakognisi Siswa dalam Menyelesaikan Masalah Matematika melalui Pendekatan Problem Solving. AKSIOMA: Jurnal Program Studi Pendidikan Matematika, 6(2), 234. https://doi.org/10.24127/ajpm.v6i2.991

Juniarta, A. T., \& Winarno, M. . (2016). Pengembangan Instrumen Penilaian Pengetahuan Mata Pelajaran Pendidikan. Jurnal Pendidikan, 1(7), 1449-1463.

Khaerunnisa, E., \& Pamungkas, A. S. (2018). Pengembangan Instrumen Kecakapan Matematis Dalam Konteks Kearifan Lokal Budaya Banten Pada Materi Bangun Ruang Sisi Datar. Kreano: Jurnal Matematika Kreatif-Inovatif, 9(1), 17-27. https://doi.org/10.15294/kreano.v9i1.11210

Marfilinda, R., Fitria, Y., \& Marsidin, S. (2019). Pengaruh Model Learning Cycle 7 E Dan Pengetahuan Awal Terhadap Keterampilan Berpikir Kritis Siswa Pada Pembelajaran Ipa Di Kelas V Sd. Jurnal Ilmiah Pendidikan Dasar, 6(2), 84. https://doi.org/10.30659/pendas.6.2.84-97

Mustikasari, V. R., Munzil, M., \& Lestari, L. P. (2018). Pengembangan Instrumen Penilaian Kemampuan Berpikir Tingkat Tinggi Materi Sistem Pendengaran dan Sonar SMP. Jurnal Eksakta Pendidikan (Jep), 2(2), 116. https://doi.org/10.24036/jep/vol2iss $2 / 212$

Putri, O. D., Nevrita, N., \& Hindrasti, N. E. K. (2019). Pengembangan Instrumen Penilaian Keterampilan Berpikir Kritis Siswa Sma Pada Materi Sistem Pencernaan. $\begin{array}{lllll}\text { BIOEDUKASI (Jurnal Pendidikan } & \text { Biologi), } & \text { 10(1), } & \end{array}$ https://doi.org/10.24127/bioedukasi.v10i1.2004 
Rodiawati, H., \& Komarudin, K. (2018). Pengembangan E-Learning Melalui Modul Interaktif Berbasis Learning Content Development System. Jurnal Tatsqif, 16(2), 172-185. https://doi.org/10.20414/jtq.v16i2.190

Saputri, N., Adlim, A., \& Inda Rahmayani, R. F. (2018). Pengembangan Instrumen Penilaian Psikomotorik Untuk Praktikum Kimia Dasar. Jurnal Tadris Kimiya, 3(2), 114-124. https://doi.org/10.15575/jtk.v3i2.3444

Sugiyono. (2010). Metode Penelitian Pendidikan Pendekatan Kuantitatif, Kualitatif, dan $R \& D$ (Cetakan Ke). Alfabeta.

Sukmawa, O., Rosidin, U., \& Sesunan, F. (2019). Pengembangan Instrumen Asesmen Kinerja (Performance Assessment) Praktikum Pada Mata Pelajaran Fisika Di Sma. Jurnal Pendidikan Fisika, 7(1), 116. https://doi.org/10.24127/jpf.v7i1.1397

Wijaya, U. R. B., Sumarni, W., \& Haryani, S. (2017). Pengembangan Instrumen Penilaian Berpikir Kritis Pada Pembelajaran Kimia Berpendekatan Sets (Science, Environment, Technology, and Society). Chemistry in Education, 6(2), 35-41. https://journal.unnes.ac.id/sju/index.php/chemined/article/view/18169 